(C) 2009 Plant Management Network.

Accepted for publication 11 December 2008. Published 30 January 2009.

\title{
Propagule Densities of Macrophomina phaseolina in Soybean Tissue and Soil as Affected by Tillage, Cover Crop, and Herbicide
}

\author{
Alemu Mengistu, Crop Genetics and Production Research Unit, \\ USDA-ARS, 605 Airway Boulevard, Jackson, TN, 38301; \\ Krishna N. Reddy and Robert M. Zablotowicz, Southern Weed \\ Science Research Unit, USDA-ARS, 141 Experiment Station Road, \\ Stoneville, MS 38776; and Allen J. Wrather, Delta Research Center, \\ University of Missouri, Portageville, MO 63873
}

Corresponding author: Alemu Mengistu. alemu.mengistu@ars.usda.gov

Mengistu, A., Reddy, K. N., Zablotowicz, R. M., and Wrather, A. J. 2009. Propagule densities of Macrophomina phaseolina in soybean tissue and soil as affected by tillage, cover crop, and herbicide. Online. Plant Health Progress doi: 10.1094/PHP-2009-0130-01RS.

\begin{abstract}
All current commercial soybean cultivars are susceptible to charcoal rot, a disease caused by Macrophomina phaseolina. Efforts to manage this disease through nongenetic means have not been effective. However, the combined effects of tillage, cover crop and herbicide use, and their roles in the population dynamics of this fungus have not been fully investigated. A field experiment was conducted in 2002 through 2004 at Stoneville, MS, to determine the population dynamics of Macrophomina phaseolina (Tassi) in soybean stem and root tissues at harvest and in soil at planting and harvest as affected by tillage, cover crop, and herbicide. The tillage treatments were conventional tillage (CT) and no-tillage (NT); the cover crops were hairy vetch, rye, and no cover crop; and the herbicide treatments were glyphosate- and non-glyphosate-based applications. Analysis of variance indicated that there was an effect due to tillage, cover crop, and tillage by year interaction on colony forming units (CFU) of $M$. phaseolina recovered from soybean tissue. Colony forming units in soybean tissue were greater under the CT than NT and were greater for hairy vetch and no cover crop than rye. Regardless of the cover crop system used, CFU in tissue was greater for CT in 2002 than in 2003 and 2004. Application of glyphosate did not affect the CFU in stem and root tissues or in the soil. The CFU from soil at harvest was significantly higher than at planting. The CFU in soil at planting and harvest was only affected by tillage and not by cover crop system. The CFU from stem and root tissues was greater than in soil suggesting that quantification of CFU in tissue may provide a better estimate of treatment effects at harvest. These results also suggest that charcoal rot may be better managed in the NT rather than in the CT system.
\end{abstract}

\section{I ntroduction}

Charcoal rot of soybean [Glycine max (L.) Merr.] caused by Macrophomina phaseolina (Tassi) Goid, is a disease of economic significance (26). Charcoal rot has been reported in the north-central states $(2,10,33)$ and throughout southern regions of the United States as well as in tropical and subtropical regions of the world (33). When severe, this disease reduces yield and seed quality (26). M. phaseolina is known to cause disease in at least 500 plant species including economic hosts such as corn, sorghum, cotton, and tobacco (33). Estimated soybean yield losses to charcoal rot for the 16 states in the southern United States have varied from year to year. However, the losses have averaged $4.7 \times$ 105 metric tons from 1999-2002 (31), making charcoal rot the most damaging disease in this region.

Severity of charcoal rot on soybean increases as ambient and soil temperatures increase $\left(28\right.$ to $\left.35^{\circ} \mathrm{C}\right)$ and as soil moisture becomes limiting $(26,32)$. A strong correlation has been observed between occurrence of drought and severity of damage to soybean due to M. phaseolina $(13,16)$. Above ground 
symptoms of charcoal rot in soybean generally appear after flowering $(25,32)$, particularly at R5, R6, and R7 grouth stages (11). Diseased plants may wilt and prematurely die with senesced leaves remaining attached to petioles. A good correlation has been established between stem and root disease severity rating and CFU (15).

Efforts to manage charcoal rot through adjusting planting dates (27), crop rotation $(12,17)$, legume cover crop (22) cultivar blends and planting densities (3), organic soil amendments (14), selection of soybean genotypes under greenhouse conditions (4), and irrigation (32) have been evaluated. These methods, however, were not very effective. Other management methods, including fungicide applications to seed and soil as well as biological control using hyperparasitism $(14,24)$, were also not effective. Host resistance may be the only feasible method to manage this disease $(4,26,32)$ but host resistance is not currently available, and other management options are needed.

Soybeans are produced in the southern United States using minimum tillage and cover crops to reduce soil erosion, water runoff, and improve soil properties. Most growers use glyphosate herbicides. The long growing season in the lower Mississippi delta region permits the use of winter cover crops in row crop production $(18,20)$. Both rye and hairy vetch have been shown to enhance certain soil microbial populations in a soybean production system $(29,34)$. Rye is often used as a cover crop because of its winter hardiness, abundant biomass production, and allelopathic nature that suppresses weeds by both physical and chemical interference $(1,8)$. Natural winter vegetation provides soil cover in certain fields, but it may not provide sufficient mulch for longer periods like cover crop residues $(18,19)$. Studies on the effect of tillage on soybean diseases are important because a significant amount of soybean production occurs under reduced or no-till system (7). Although some studies have examined the effects of cover crops and tillage on M. phaseolina populations in soil $(21,30)$, there is limited information on the impact of soybean production under cover crop, notill and glyphosate based systems on charcoal rot. The objective of this study was to determine the effects of tillage, cover crops, and herbicides on the population dynamics of M. phaseolina in stem and root tissue as well as in soil at planting and at harvest.

\section{Studying Affects on M. phaseolina Population}

A field experiment was conducted in Stoneville, MS $\left(33^{\circ} 26^{\prime} \mathrm{N}, 90^{\circ} 55^{\prime} \mathrm{W}\right)$ from 2002 to 2004 on a Dundee silt loam soil (fine-silty, mixed, active, thermic Typic Endoaqualf) with $26 \%$ sand, 56\% silt, and $18 \%$ clay. This was part of an agronomic study that has been previously published (19). Cover crop treatments consisted of rye, hairy vetch, or no-cover crop. Rye and hairy vetch were drilled in 19-cm-wide rows using a no-till grain drill in mid-October each year. Plants in the entire experimental area were killed with paraquat at $1.1 \mathrm{~kg}$ ai $/$ ha in midApril each year. The two tillage treatments were no tillage (NT) and conventional tillage (CT). The NT plots received no tillage operations after the fall of 1997. After cover crop desiccation, the CT plots were tilled with a disk harrow and a field cultivator to thoroughly incorporate the plant residue before soybean planting. In NT plots, the desiccated cover crops were left undisturbed. The CT and NT plots were not tilled between harvest and planting of cover crops in the fall. Plant biomass in the no cover crop treatment was from volunteer winter annuals. The glyphosate resistant soybean cultivar 'AG 4702RR' was planted on 2 May 2002, 30 April 2003, and 3 May 2004. The two herbicide treatments were glyphosate- and non-glyphosate conventional herbicides applied post-emergence. In glyphosate-based treatment, two applications of glyphosate at $0.84 \mathrm{~kg}$ ai/ ha were applied. In non-glyphosate-based treatment, acifluorfen at $0.28 \mathrm{~kg}$ ai $/$ ha plus bentazon at $0.56 \mathrm{~kg}$ ai/ ha, chlorimuron at $5 \mathrm{~g}$ ai/ ha and clethodim at $0.14 \mathrm{~kg}$ ai/ ha or fluazifop-P at $0.28 \mathrm{~kg}$ ai/ ha were used. Postemergence herbicides were applied between 3 to 7 weeks after soybean planting. Herbicide treatments were applied with a tractor-mounted sprayer with 8004 standard flat spray tips delivering 187 liter/ha water at $179 \mathrm{kPa}$. No preemergence herbicides were used in the study. The experimental plots were not irrigated. The experiment was conducted in a split-split plot arrangement of 
treatments in a randomized complete block design with tillage (CT and NT) as the main plot, cover crops (rye, hairy vetch, no-cover crop) as the subplot, and herbicide programs (glyphosate and conventional herbicide) as the sub-subplot with four replications. Each sub-subplot consisted of 4 rows spaced $102 \mathrm{~cm}$ apart and was $24.3 \mathrm{~m}$ long. The same treatment was assigned to the same plot every year. Since the experiment was conducted on the same site for 3 years, years were treated as repeated measurements and included in the analysis as another split.

Determination of population density and statistical analysis. In a previous study (15), the correlation between disease severity and CFU was significant, and it was suggested that CFU in soybean tissue could be used as a measure of disease severity when precise measurement of treatment effects is needed. Ten plants per plot were randomly selected at the R7 growth stage (23) and the lower stem and root was separated from the stem at the cotyledonary node. The root and stem tissue samples from each plot were thoroughly washed and rinsed in water to remove soil, air dried, and stored at $25^{\circ} \mathrm{C}$. The stem and root tissues were ground with a Wiley Mill Model 4 (Philadelphia, PA) and passed through a 1-mm mesh screen. The mill was thoroughly cleaned between samples with a suction device. For each sample, $5 \mathrm{mg}$ ground tissue was mixed in a waring blender with $100 \mathrm{ml}$ of $0.525 \% \mathrm{NaOCL}$ and for $3 \mathrm{~min}$, the filtrate was collected over a $45-\mu \mathrm{m}$ pore size sieve, and the ground tissue was rinsed with sterile distilled water.

To determine soil population $(15,25)$ at planting and at harvest, ten core soil samples were collected from the upper 0 to $5 \mathrm{~cm}$ depth of soil. The soil was thoroughly mixed, and a 5-g subsample was removed, ground with mortar and pestle, and passed through a 600- $\mu \mathrm{m}$ sieve. A 1-g subsample was homogenized in a waring blender with $100 \mathrm{ml}$ of $0.525 \% \mathrm{NaOCL}$ for $1 \mathrm{~min}$, and the filtrate was collected on a 45- $\mu \mathrm{m}$ pore size sieve and rinsed with sterile water. The triturates recovered from stem and root tissue and soil samples were separately added to $100 \mathrm{ml}$ of potato dextrose agar (PDA) that had been autoclaved, cooled to $60^{\circ} \mathrm{C}$, and amended with rifampicin $(100 \mathrm{mg} /$ liter $)$ and tergitol $(0.1 \mathrm{ml})(24,25)$. Each sample was distributed evenly into five Petri dishes. After 3 days of incubation at $30^{\circ} \mathrm{C}$, the CFU of $\mathrm{M}$. phaseolina were counted and the number expressed as CFU per gram of tissue or dry soil. Identification of M. phaseolina colonies was based on characteristically gray to black colonies with sclerotia $(23,26)$.

Analysis of variance was performed on CFU recovered from tissue and soil at planting and harvest for all treatments. PROC MIX and Fisher's least significant differences were used for mean separation using SAS (SAS Institute Inc., Cary, NC). Soil data was $\log _{10}$ transformed since there were zero values in the CFU data and the data was back transformed after analysis.

\section{Tillage and Cover Crop Effects on CFU from Lower Stems and Roots}

The CFU for CT was significantly greater than for the NT when averaged across years and cover crops (Fig. 1A). The CFU for the CT was about twice that of the NT. When the three cover crop systems were averaged across tillage and years, rye had significantly fewer CFU, while hairy vetch or no cover crop had the highest CFU of M. phaseolina (Fig. 1B). When the CFU value for each cover crop and year is assessed (Fig. 2), the CFU under the CT was 3915, 4185, and 3450 , under no cover crop, while it was 3390, 3300, and 2800 under rye, and was 5775, 4625, and 3800 under hairy vetch cover crop in 2002, 2003, and 2004, respectively. The CFU for the NT was 1925, 2110, and 1750 under no cover crop; it was 825, 1630, and 1350 under rye cover crop, and it was 2400, 2755, and 2350 under hairy vetch cover crop in 2002, 2003, and 2004, respectively. 

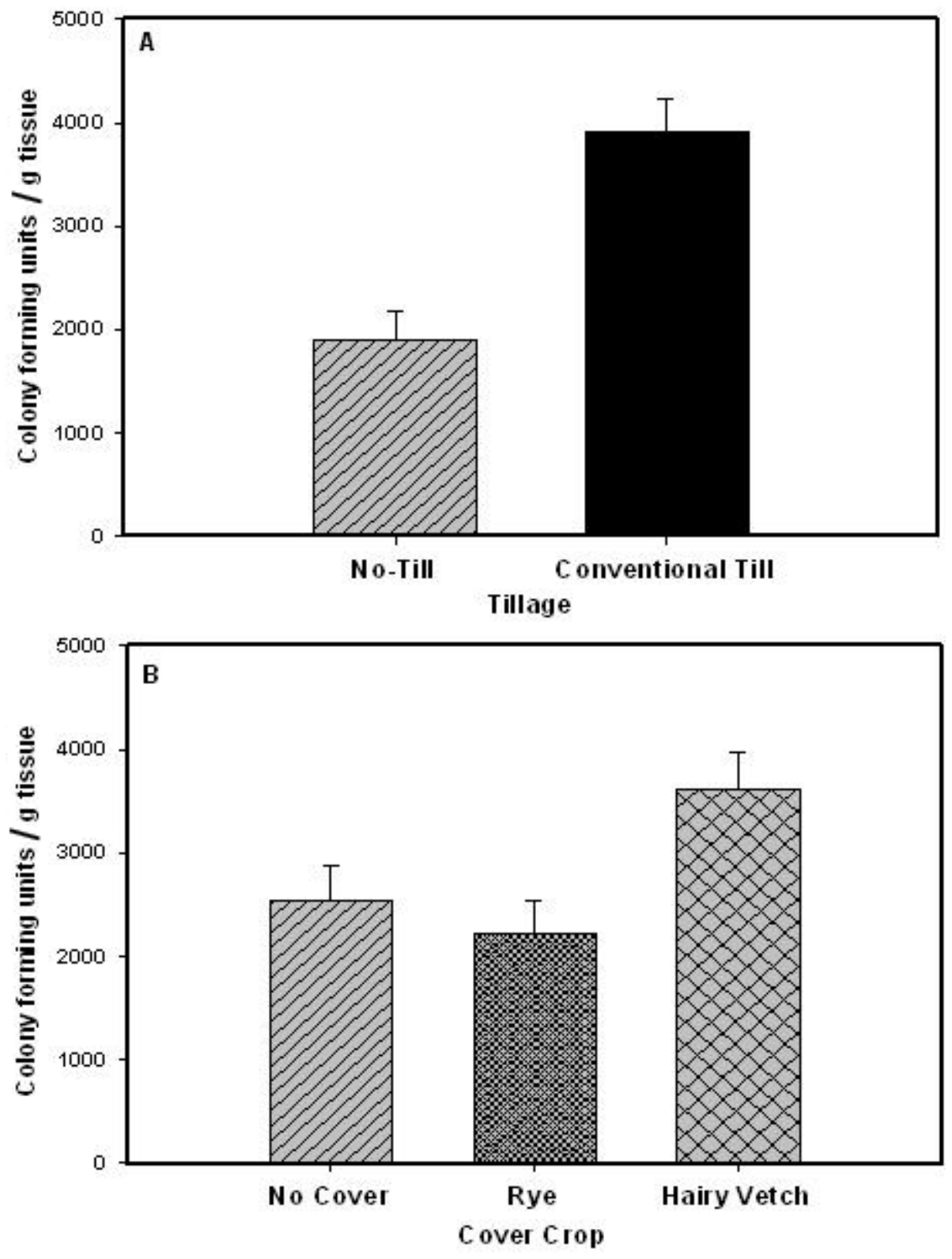

Fig. 1. Main effects of tillage when averaged across years and cover crops $(A)$ and cover crop when averaged across tillage and years (B) on colony forming units of M. phaseolina from lower stem and root tissues of soybeans sampled at R7 growth. 


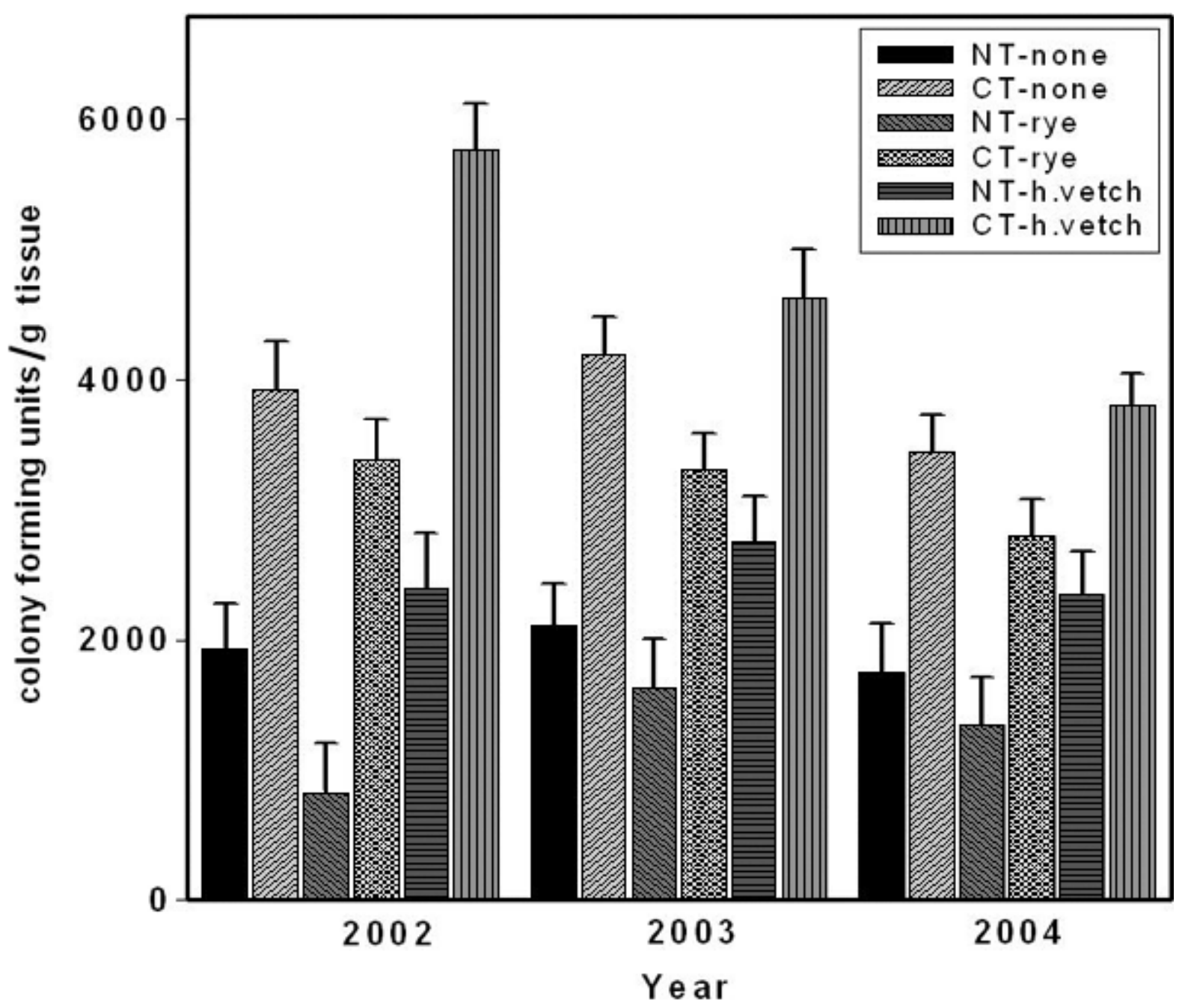

Fig. 2. Effect of tillage and cover crops on colony forming units for each cover crop and year of M. phaseolina from lower stem and root tissues of soybeans sampled at R7 growth stage in 2002, 2003, and 2004.

Analysis of the test of fixed effects for CFU of M. phaseolina from lower stems and root tissues indicated that there were significant effects due to tillage, cover crop, and tillage by year interaction (Table 1). The main effects across all variables indicated that CFU was significantly higher for CT (3916) than for the NT (1900). Across all factors, CFU under hairy vetch (3618) was significantly higher than the CFU under rye (2216) or no cover (2546). Rye had 39\% less CFU than hairy vetch and $13 \%$ less than no cover crop. There was no effect of continuous herbicide regime each year on CFU with glyphosate and conventional herbicide management. The interaction of tillage by year indicates that the CFU was higher in 2002 under CT than the corresponding CFU in 2003 and 2004. Similarly, the CFU for CT in 2003 was higher than the corresponding CFU in 2004. However, the CFU in 2002, 2003, and 2004 under the NT system did not change during the 3 years. 
Table 1. Analysis of tests of fixed effects of tillage, cover crop and herbicide and their interactions on CFU of M. phaseolina from lower stem and root tissues in 2002 through 2004.

\begin{tabular}{|c|c|c|c|}
\hline Effect $^{X}$ & DF & F value & $\mathbf{P R}>\mathbf{F}$ \\
\hline Til & 1 & 6.23 & 0.01 \\
\hline $\mathrm{CC}$ & 2 & 3.89 & 0.02 \\
\hline Til*CC & 2 & 0.02 & 0.98 \\
\hline herb & 1 & 0.30 & 0.59 \\
\hline til*herb & 1 & 0.12 & 0.73 \\
\hline CC* herb & 2 & 0.36 & 0.70 \\
\hline til*CC* herb & 2 & 0.33 & 0.72 \\
\hline Year & 2 & 2.23 & 0.11 \\
\hline Til*Year & 2 & 3.11 & 0.05 \\
\hline CC*Year & 4 & 2.21 & 0.07 \\
\hline Til*CC*Year & 4 & 0.47 & 0.76 \\
\hline Herb*Year & 2 & 2.77 & 0.07 \\
\hline Til*herb*Year & 2 & 1.69 & 0.19 \\
\hline CC* herb*year & 4 & 1.74 & 0.15 \\
\hline Til*CC*herb*Year & 4 & 0.09 & 0.98 \\
\hline Random effects ${ }^{y}$ & & \multicolumn{2}{|c|}{ Variance component } \\
\hline Block & & \multicolumn{2}{|c|}{0} \\
\hline Til*block & & \multicolumn{2}{|c|}{0} \\
\hline CC*block(Til) & & \multicolumn{2}{|c|}{0} \\
\hline Residual & & \multicolumn{2}{|c|}{5510560} \\
\hline
\end{tabular}

$\mathrm{x}$ Til $=$ tillage, $\mathrm{CC}=$ cover crop, Herb $=$ herbicide.

y Random and variance components indicate plot to plot variability within a year and whole plot is the only real source of error (residual).

As treatments were applied to the same plots each year, it would seem appropriate that the results at the end of the final year (2004) should be indicative of their repeated effect. However, there was a decline in CFU in 2004 compared to 2002 and 2003 under CT, when hairy vetch was used as a cover crop. A decline in CFU did not occur under the NT system. The decline in CFU under CT may have been attributed to weather conditions in 2003 and 2004 when there was more rainfall than in 2002. Results reported by Reddy et al. (19) indicated that inorganic nitrate levels in hairy vetch plots have been found to be two- to three-fold higher compared to no cover crop, or rye cover crop. It may be possible that such an increase in inorganic nitrate may have led to an increase in microorganisms that are antagonistic to M. phaseolina as a result of a continuous hairy vetch cover crop and its incorporation every year into the soil. This reduction in CFU corroborates with other findings that disease severity of black root rot caused by Thielaviopsis basicola $(6,9,22)$ and Fusarium wilt of watermelon (35) was suppressed by hairy vetch. In these reports, suppression was attributed to a release of ammonia that was inhibitory to propagule development of these organisms during the degradation of the hairy vetch residues. It is important to note here that a similar reduction did not occur under NT when hairy vetch was used as a cover crop each year.

Data gathered on climatic conditions at the research station (28) (Table 2) indicated that there was a $3 \%$ and a $4 \%$ increase in air and soil temperatures, respectively, in 2002 compared to the 30 year average. There was also a reduction of $21 \%$ and $71 \%$ in precipitation during J une through August for 2002 compared to the 30-year average. Higher average air and soil temperatures and decreased precipitation during the critical months of J une, J uly, and August in 2002 (Table 2) which would have put more stress on the plants and may have 
contributed to conditions that significantly raised the level of CFU in 2002. It is important to also note that during these stress periods, the CFU under the CT exceeded that of the NT. Infections due to M. phaseolina remain latent until environmental stresses coincide with growth stages R1 to R7. During these stress periods, the CFU in root and lower stem tissues increase as the soybean plant matures (26).

Table 2. Daily mean values of air temperature, precipitation, pan evaporation, solar radiation and soil temperature from 2002, 2003, 2004, and a 30-year average for the critical months of June, July and August.

\begin{tabular}{|l|c|c|c|c|c|}
\hline Year & $\begin{array}{c}\text { Air temp. } \\
\left({ }^{\circ} \mathrm{C}\right)\end{array}$ & $\begin{array}{c}\text { Precip. } \\
(\mathrm{mm})\end{array}$ & $\begin{array}{c}\text { Pan } \\
\text { evaporation } \\
(\mathrm{mm})\end{array}$ & $\begin{array}{c}\text { Solar } \\
\text { radiation } \\
(\text { Langleys })\end{array}$ & $\begin{array}{c}\text { Soil } \\
\text { temp. } \\
\left({ }^{\circ} \mathrm{C}\right)\end{array}$ \\
\hline 2002 & 33.3 & 2.54 & 7.62 & 424 & 39.4 \\
\hline 2003 & 32.8 & 3.3 & 5.84 & 519 & 37.8 \\
\hline 2004 & 31.7 & 5.08 & 5.08 & 518 & 37.2 \\
\hline 3-year average & 32.8 & 3.56 & 6.1 & 487 & 38.3 \\
\hline 30-year average & 32.2 & 2.54 & 5.33 & 539 & 37.8 \\
\hline
\end{tabular}

$x$ The 30 year average was a data taken from 1971-2000.

$y$ The method for measuring solar radiation changed several times over the 30 year period. The current method used for measuring solar radiation is a li-cor pyranometer (28).

Tillage and Cover Crop Effects on CFU from Soil

Analysis of variance on transformed CFU data from soil indicated that there were significant effects due to tillage, sampling, and the interactions of tillage by sampling, tillage by year, sampling by year, tillage by sampling by year, and tillage by cover crop by sample by year (Table 3 ). There was no year, cover crop, or herbicide effect. Across all factors, the main effect of tillage was significant with CFU means of 37/g and 47/g at planting and harvest respectively. Soil sampled at planting had significantly lower CFU (18 CFU/g soil) than soil sampled during harvest ( $66 \mathrm{CFU} / \mathrm{g}$ soil). Even though there was no effect due to year, the CFU in 2002 in CT at harvest exceeded that of NT as well as the CFU for CT in 2003 and 2004 (Fig. 3).

There was a decline in CFU in soil for the CT from 2002 to 2003, but the CFU level did not change significantly from 2003 to 2004. The CFU at planting remained much lower than the CFU at harvest for each year under both the NT and CT. The CFU at planting increased for both the NT and CT in 2003 and 2004 relative to 2002. There was no difference between the NT and CT within each sampling period within each year. The data from soil samples indicates that 2002 is the only year, when major differences occurred between treatments after which their effects were not significant within sampling time and between the effects of cover crops. The CFU value from samples at harvest was ten to thirty fold less than the CFU from stem and root tissues (Fig. 2 and Fig. 3). 
Table 3. Analysis of type 3 fixed effects of tillage, cover crop, herbicide, sampling date and their interactions for soil sampled at planting and harvest on CFU of M. phaseolina in 2002 through 2004.

\begin{tabular}{|c|c|c|c|}
\hline Effect1 & DF & F Value & $\operatorname{Pr}>\mathbf{F}$ \\
\hline Til & 1 & 14.72 & 0.0316 \\
\hline $\mathrm{CC}$ & 2 & 0.33 & 0.72 \\
\hline Til*CC & 2 & 1.27 & 0.28 \\
\hline Sample & 1 & 324.78 & $<0.01$ \\
\hline Til*Sample & 1 & 10.53 & 0.01 \\
\hline CC*Sample & 2 & 0.34 & 0.70 \\
\hline Til*CC*Sample & 2 & 1.09 & 0.34 \\
\hline Herb & 1 & 1.47 & 0.23 \\
\hline Til*Herb & 1 & 5.23 & 0.09 \\
\hline CC*Herb & 2 & 0.35 & 0.70 \\
\hline Til*CC*Herb & 2 & 0.32 & 0.73 \\
\hline Herb*Sample & 1 & 0 & 0.99 \\
\hline Til*Herb*Sample & 1 & 3.33 & 0.07 \\
\hline CC*Herb*Sample & 2 & 0.39 & 0.68 \\
\hline Til*CC*herb*Sample & 2 & 0.83 & 0.44 \\
\hline Year & 2 & 0.37 & 0.69 \\
\hline Til*Year & 2 & 19.43 & $<0.01$ \\
\hline CC*Year & 4 & 0.59 & 0.67 \\
\hline Til*CC*Year & 4 & 2.74 & 0.03 \\
\hline Sample*Year & 2 & 37.70 & $<0.01$ \\
\hline Til*Sample*Year & 2 & 15.64 & $<0.01$ \\
\hline CC*Sample*Year & 4 & 1.27 & 0.28 \\
\hline Til*CC*Sample*Year & 4 & 2.82 & 0.03 \\
\hline Herb*Year & 2 & 0.25 & 0.78 \\
\hline Til*Herb*Year & 2 & 0.19 & 0.83 \\
\hline CC*Herb*Year & 4 & 0.55 & 0.70 \\
\hline Til*CC*Herb*Year & 4 & 0.74 & 0.56 \\
\hline Herb*Sample*Year & 2 & 0.05 & 0.95 \\
\hline Til*Herb*Sample*Year & 2 & 0.74 & 0.48 \\
\hline CC*herb*Sample*Year & 4 & 1.12 & 0.35 \\
\hline Random effects ${ }^{y}$ & & \multicolumn{2}{|c|}{ Variance component ${ }^{y}$} \\
\hline Block & & \multicolumn{2}{|c|}{1.5118} \\
\hline Til*Block & & \multicolumn{2}{|c|}{0.9809} \\
\hline CC*Block (til) & & \multicolumn{2}{|c|}{0} \\
\hline Residual & & \multicolumn{2}{|c|}{507.04} \\
\hline
\end{tabular}

${ }^{x}$ Til $=$ tillage, $C C=$ cover crop, Herb $=$ herbicide.

$y$ Random and variance components indicate that plots from the main effects of NT and CT show a larger error than sub plots within each whole plot and the overall block has an effect in reducing error. 


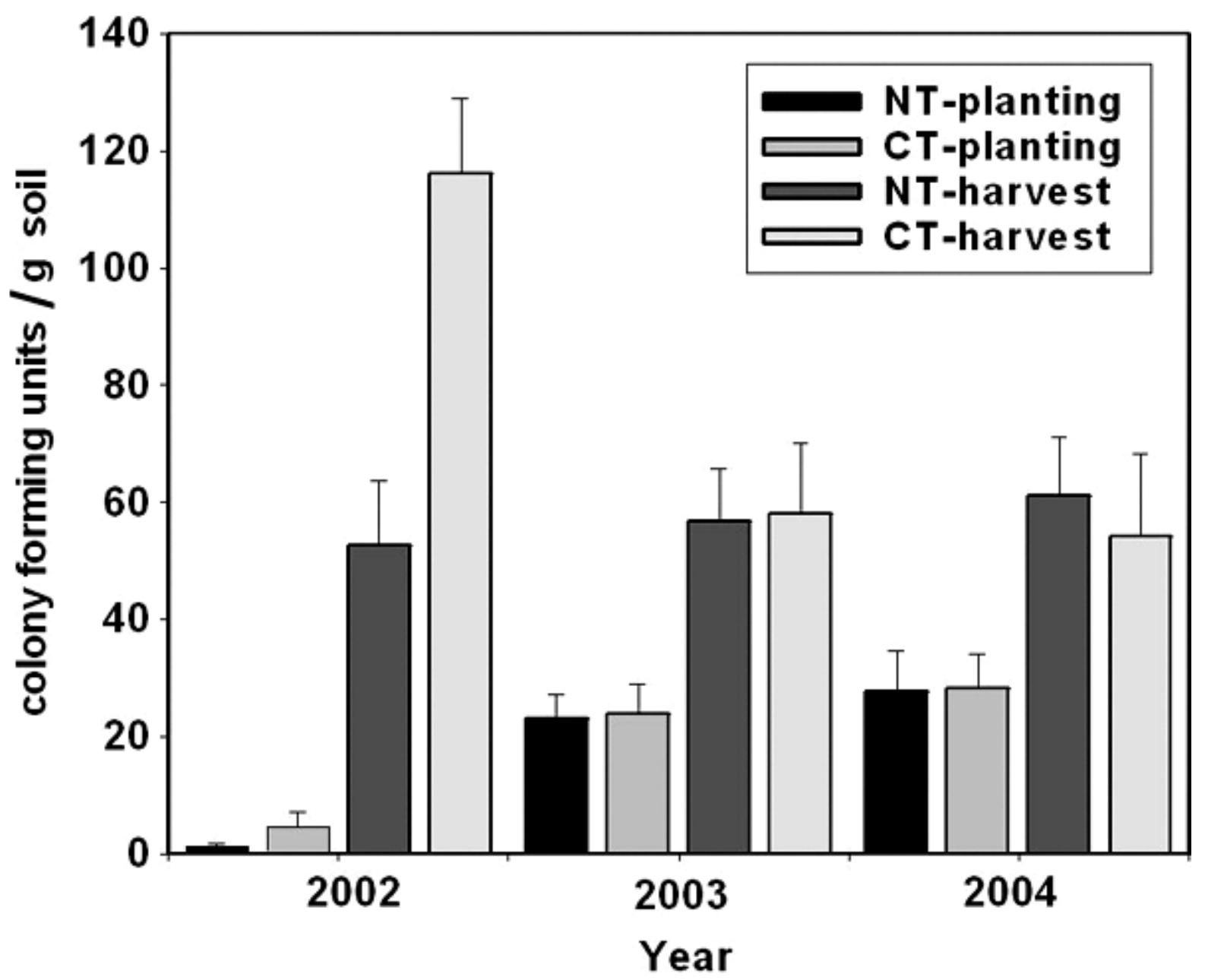

Fig. 3. Effect of tillage from soil sampled at planting and harvest on the colony forming units of M. phaseolina for 2002, 2003, and 2004.

\section{Discussion}

This study demonstrated that the NT system had fewer CFU of M. phaseolina in root and stem tissues than the CT system indicating that NT may provide a less conducive environment to support the M. phaseolina population. This result is contrary to the findings of Wrather et al. (30) in which tillage did not affect M. phaseolina population density. Their data was based on soil samples taken only at planting and did not include population density from plant tissue and from soil during harvest. Our data is in agreement with their findings when a soil population was determined solely using soil samples taken at planting.

The CFU reduction due to NT may be due to a cooler soil temperature effect under the NT cropping system because of a high volume of crop residue on the soil surface. Such high volume of residue also increases soil moisture retention in NT compared to CT.

Based on the CFU from stem and root tissue, hairy vetch as a cover crop significantly increased M. phaseolina under CT and NT suggesting that hairy vetch is a very susceptible host and increased the level of CFU of M. phaseolina, particularly in drier years. In contrast, CFU from soybean root and stem tissues was lower for rye than hairy vetch or no cover crop, and may be useful as a charcoal rot management tool. Rye produces a composite of allelopathic compounds (1). These allelopathic compounds may directly restrict the increase in inoculum load of $\mathrm{M}$. phaseolina that may have resulted in low CFU count.

The lower CFU value in soil at planting than harvest was expected since additional microsclerotia of $\mathrm{M}$. phaseolina may have been added to soil from crop residues at harvest. However, the data suggest that the inoculum at harvest did not influence the subsequent inoculum at planting. The data also suggests 
that soil CFUs are generally less sensitive to detect treatment differences compared to CFU from stem and root tissues that produced higher CFU values for the same treatment.

Neither the conventional nor the glyphosate herbicides affected CFU of M. phaseolina under the two tillage and three cover crop systems in this study. This is in agreement with the findings of Wyille (32) and Canaday (5) that glyphosate and conventional herbicides had no effect on M. phaseolina other than minor effects associated with root injury. The data showed that inoculum levels of $\mathrm{M}$. phaseolina may be reduced more under the NT than the CT system. Quantification of propagule density of $\mathrm{M}$. phaseolina also may be better estimated using lower stem and root soybean tissues than soils to detect treatment differences. The data suggested that the practice of leaving soybean fields fallow for three years or less did not eliminate or reduce the level of CFU of M. phaseolina.

\section{Acknowledgments and Disclaimer}

We acknowledge the excellent assistance with data analysis from Debbie Boykin, USDA statistician. We also thank Avis Clark, Albert Tidwell and Earl Gordon for their assistance in lab and field tests.

Mention of trade names or commercial products in this publication is solely for providing specific information and does not imply recommendation or endorsement by the U.S. Department of Agriculture.

\section{Literature Cited}

1. Barnes, J . P., and Putnam, A. R. 1986. Evidence for allelopathy by residues and aqueous extracts of rye (Secale cereale). Weed Sci. 34:384-390.

2. Birrenkott, G. L., Mengistu, A., and Grau, C. R. 1984. First report of charcoal rot caused by Macrophomina phaseolina on soybeans in Wisconsin. Plant Dis. 68:628.

3. Bowen, C. R., and Schapaugh, W. T., Jr. 1989. Relationship among charcoal rot infection, yield, and stability estimates in soybean blends. Crop Sci. 29:42-46.

4. Bristow, W. E., and Wyllie, T. D. 1984. Reaction of soybean cultivars to Macrophomina phaseolina as seedlings in the growth chamber and field. Trans. Mo. Acad. Sci. 18:5-10.

5. Canaday, C. H., Helsel, D. G., and Wyllie, T. D. 1986. Effects of herbicide induced stress on root colonization of soybeans by Macrophomina phaseolina. Plant Dis. 70:863-866.

6. Candole, B. L., and Rothrock, C. S. 1998. Using marked strains to assess the effect of hairy vetch amendment on the inoculum densities of Thielaviopsis basicola, Pythium ultimum and Rhizoctonia solani. Soil Biol. Biochem. 30:443-448.

7. CTIC. 2004. National Crop Residue Management Survey. Conservation Technology Information Center (CTIC), West Lafayette, Indiana.

8. Creamer, N. G., Bennett, M. A., Stinner, B. R., Cardina, J ., and Reginer, E. E. 1996. Mechanisms of weed suppression in cover crop-based production systems. HortScience 31:410-413.

9. Delgado, A., Franco, G. M., Vega, J . M., Carmona, E., and Aviles, M. 2006. Incidence of cotton seedling diseases caused by Rhizoctonia solani and Thielaviopsis basicola in relation to previous crop, residue management and nutrients availability in soils in SW Spain. J . Phytopathol. 154:710-714.

10. ElAraby, M. E., Kurle, J . E., and Stetina, S. R. 2003. First Report of Charcoal Rot (Macrophomina phaseolina) on Soybean in Minnesota. Plant Dis. 87:202.

11. Fehr, W. R., Caviness, C. E., Burmood, D. T., and Pennington, J. S. 1971. Stage of development descriptions for soybeans, Glycine max (L.) Merrill. Crop Sci. 11:929-931.

12. Francl, L. J., Wyllie, T. D., and Rosenbrock, S. M. 1988. Influence of crop rotation on population density of Macrophomina phaseolina in soil infested with Heterodora glycines. Plant Dis. 72:760-764.

13. Gary, F. A., Mihail, J. D., Lavigne, R. J., and Porter, P. M. 1991. Incidence of charcoal rot of sorghum and soil populations of Macrophomina phaseolina associated with sorghum and native vegetation in Somalia. Mycopathologia 114:145-151.

14. Ghaffer, A., Zentmyer, G. A., and Erwin, D. C. 1969. Effect of organic amendments on severity of Macrophomina phaseolina root rot of cotton. Phytopathology 59:1267-1269. 
15. Mengistu, A., Ray, J . D., Smith, J . R., and Paris, R. L. 2007. Charcoal rot disease assessment of soybean genotypes using a colony forming unit index. Crop Sci. 47:2453-2461.

16. Manici, L. M., Caputo, F., and Cerato, C. 1995. Temperature responses of isolates of Macrophomina phaseolina from different climatic regions of sunflower production in Italy. Plant Dis. 79:934-938.

17. Mueller, J . D., Short, B. J ., and Sinclair, J . B. 1985. Effect of cropping history, cultivar, and sampling date on the internal fungi of soybean roots. Plant Dis. 69:520-523.

18. Reddy, K. N. 2001. Effects of cereal and legume cover crop residues on weeds, yield, and net return in soybean (Glycine max). Weed Technol. 15:660-668.

19. Reddy, K. N., Zablotowicz, R. M., Locke, M. A., and Koger, C. H. 2003. Cover crop, tillage, and herbicide effects on weeds, soil properties, microbial populations, and soybean yield. Weed Sci. 51:987-994.

20. Reddy, K. N., Zablotowicz, R. M., Locke, M. A., and Koger, C. 2004. Cover crop, tillage, and herbicide effects on weeds, soil properties, microbial populations, and soybean yield in the lower Mississippi delta. Weed Sci. 51:987-994.

21. Rothrock, C. S., and Hargrove, W. L. 1988. Influence of legume cover crops and conservation tillage on soil populations of selected fungal genera. Can. J . Microbiol. 201-206.

22. Rothrock, C. S., and Kirkpatrick, T. L. 1995. The influence of winter legume cover crops on soilborne plant pathogens and cotton seedling diseases. Plant Dis. 79:167-171.

23. Short, G. E., Wyllie, T. D., and Ammon, V. D. 1978. Quantitative enumeration of Macrophomina phaseolina in soybean tissues. Phytopathology 68:736-741.

24. Siddiqui, Z. A., and Mahmood, I. 1993. Biological control of Meloidogyne incognita race 3 and Macrophomina phaseolina by Paecilomyces lilacinus and Bacillus subtilis alone and in combination in chickpea. Fund. Appl. Nematol. 16:215-218.

25. Smith, G. S., and Carvil, O. N. 1997. Field Screening of commercial and experimental soybean cultivars for their reaction to Macrophomina phaseolina. Plant Dis. 81:363-368.

26. Smith, G. S., and Wyllie, T. D. 1999. Charcoal rot. Pages 29-30 in: Compendium of Soybean Diseases, 4th Edn. G. C. Hartman, J . B. Sinclair, and J . C. Rupe, eds. American Phytopathological Society, St. Paul, MN.

27. Todd, T. C. 1993. Soybean planting date and maturity effects on Hetrodera glycines and Macrophomina phaseolina on southeastern Kansas. Suppl. J . Nematol. 25:731-737.

28. USDA-ARS-MSA. 2005. Statistical services (home page). Online. USDA-ARS MidSouth Area (MSA), Stoneville, MS.

29. Wagner, S. C., Zablotowicz, R. M., Locke, M. A., Smeda, R. J ., and Bryson, C. T. 1995. Influence of herbicide-desiccated cover crops on biological soil quality in the Mississippi Delta. Pages 86-89 in: W. L. Kingery and N. Buehring, eds. Conservation Farming: A Focus on Water Quality. MAFES Spec. Bull. 88-7. Proc. of the 1995 S. Conservation Tillage Conference for Sustainable Agric. Mississippi State Univ., Mississippi State, MS.

30. Wrather, J . A., Kendig, S. R., and Tyler, D. D. 1998. Tillage effects on Macrophomina phaseolina population densities and soybean yield. Plant Dis. 82:247-250.

31. Wrather, J . A., Koenning, S. R., and Anderson, T. R. 2008. Effect of Diseases on soybean yields in the United States and Ontario (1999 to 2002). Online. Plant Health Progress doi:10.1094/ PHP-2003-0325-01-RV.

32. Wyllie, T. D. 1988. Charcoal rot of soybean- current status. Pages 106-113 in: Soybean Diseases of the North Central Region. T. D. Wyllie and D. H. Scott, eds. American Phytopathological Society, St. Paul, MN.

33. Yang, X. B., and Navi, S. S. 2005. First Report of Charcoal Rot Epidemics Caused by Macrophomina phaseolina in Soybean in Iowa. Plant Dis. 89:526.

34. Zablotowicz, R. M., Locke, M. A., and Smeda, R. J. 1998. Degradation of 2, 4-D and fluometuron in cover crop residues. Chemosphere 37:87-101.

35. Zhou, H. G., and Evert, K. L. 2004. Suppression of Fusarium wilt of watermelon by soil amendment with hairy vetch. Plant Dis. 88:1357-1365. 